\title{
EFFICIENCY OF LEGAL WAYS TO FIGHT AGEISM ON THE LABOR MARKET IN THE RUSSIAN FEDERATION
}

\author{
Fatima O. Suleymanova ${ }^{1}$
}

\begin{abstract}
The relevance of the research is due to the fact that in Russia, same as elsewhere in the world, the ratio of older persons increases, so increases the proportion of employed older persons. This study is aimed at describing the position of older people in the labor market for both those who have the status of a retired and those who do not have this status. The paper studies the impact of the retirement age increase on employment in the labor market, assesses the adequacy and efficiency of additional legal guarantees introduced due to the increase in the retirement age (criminal liability for the denial of employment, release from work due to annual physical, etc.). The study tries to find out how Russian labor legislation is adapted to solve problems that arise from age, and whether it is able to counteract ageism in the labor market. The research was conducted by analyzing international and Russian legislation that determines the retirement age, and the
\end{abstract} impact of the retirement age on labor market rights and employee status. The existing special legal norms regulating the labor of retired and pre-retired employees, as well as norms aimed at overcoming ageism, are considered comprehensively. In particular, the paper concludes that the current norms for regulating the labor of employed pensioners and pre-retirees are insufficient; the norms on fixed-term employment contracts with elderly pensioners are discriminatory; the criminal liability for the denial of employment of pre-retirees is inefficient, and so on. The materials of the paper may be helpful in improving the current labor and social legislation aimed at supporting older age groups in the labor market.

Keywords: older persons, ageism, retirement age increase, labor rights, employment.

\footnotetext{
${ }^{1}$ National Research University 'Higher School of Economics', Moscow, Russia. Email: fsuleymanova@hse.ru
} 


\section{I}

GÊNERO E

INTERDISCIPLINARIDADE

\section{Introduction}

The international labour organization in its anniversary report of the Global Commission on the Future of Labor has aimed at ensuring universal social protection from birth to old age. The future of the world of labor requires a strong and responsive social protection system that helps meet the needs of people throughout their lives (Report of the Global Commission ... 2019). Each stage of life has its own specifics. With age, the vulnerability in the labor market increases, and citizens become less attractive to employers. After the disability, the risks of poverty increase.

Thus, taking into account international recommendations and national demographic, economic, cultural, and other characteristics, each state should determine the range of citizens who need protection due to age, and construct a support system for them. However, most international instruments deal mainly with material support in case of retirement due to reaching the age of inability to work.

Growing economic activity of the elderly results in constantly increasing ratio of employees of retirement age. Surveys of the population in Russia on employment issues show
$\mathrm{Vol}^{\circ} 02$ | nº 01 | ISSN: $2675-7451$

https://www.periodicojs.com.br/index.php/gei/index

that from 1995 to 2015, the share of economically active men aged 60 to 72 years increased from 17.4 to $28.5 \%$, and the share of economically active women in the same age group - from 7.9 to $19 \%$. Today, $53.8 \%$ of the 'young retired' aged 55-59 years are economically active, compared to $31.2 \%$ in 1995 (Klepikova, Kolosnitsyna, n.d.).

The position of citizens in the labor market becomes unstable with age, and the risks of losing their jobs and earnings increase. If the guarantees of income when it is impossible to find a job after retirement age are provided by special financial support systems, then the citizens have to bear the risks by themselves.

In the global report 'Equality at work: finding answers to challenges', presented due to the mechanism for implementing the ILO Declaration on fundamental principles and rights at work in 2007, age discrimination is among the recently recognized forms of discrimination (ILO global report 'Equality...).

Modern research in developed countries refutes the stereotypes that elderly workers are in poor health and unable to learn (Biggs, Carstensen, Hogan, 2012). 


\section{I}

GÊNERO E INTERDISCIPLINARIDADE

Building a state social policy regarding social protection of citizens due to age, requires measures that are either aimed at older citizens who lose their ability to work due to age and have specific needs or their volume increases, or citizens who are able to work, but due to existing practices and stereotypes face difficulties in the labor market.

In the latter case, state support is less costly financially, but much more difficult to implement, same as any fight against discrimination in any field. Despite the fact that legal regulation in the field of protection against discrimination in Russia has been somewhat improved in recent years, legal protection measures are still insufficient.

Due to the sharp increase in the retirement age in Russia and the need to mitigate the negative social consequences, the Russian legislator turned to the topic of providing social guarantees to older citizens. The pension reform led to the emergence of a new category of people - "pre-retirees" (5 years before the retirement age). However, the guarantees provided to them relate mainly to the preservation of previous benefits and are not related to obstacles in the labor market that citizens
$\operatorname{Vol}^{\circ} 02\left|n^{\circ} 01\right|$ ISSN: 2675-7451

https://www.periodicojs.com.br/index.php/gei/index

face much earlier than the retirement and even pre-retirement age.

This raises a number of questions. The main question is from what time (age) are support measures needed and what should they be?

\section{Materials and methods}

In order to achieve the goals of this study - to assess the efficiency of existing legal norms aimed at social support of persons due to age in the labor market, the current international and Russian legal norms were studied.

To determine the age of need for social guarantees, and especially the retirement age, the studies of both Soviet and modern scientists in economy, lawyers, psychologists, etc. are given. Thus, the analysis used the works by such scientists as Azarova E. G., Kozlov A. E. (1983). Lichnost' i sotsial'noe obespechenie v SSSR [Personality and social security in the USSR]. Moscow, 80; Acharkan, V. A. (1973). Aktual'nyye problemy pensionnogo obespecheniya [Relevant problems of pension provision]. In: Dokhody trudyashchikhsya i sotsial'nyye problemy urovnya zhizni naseleniya $\mathrm{v}$ SSSR. Moscow Gamezo, M.V., Gerasimova, B.C., Gorelova, G.G., 


\section{I}

\section{GÊNERO E} INTERDISCIPLINARIDADE

Orlova, L.M. (1999). Vozrastnaya psikhologiya: lichnost' ot molodosti do starosti [Developmental psychology: personality from youth to old age]; Denisenko, M. B., Varshavskaya, E. Ya. (2017). Prodolzhitel'nost' trudovoy zhizni v Rossii [Working life duration in Russia]. Ekonomicheskiy zhurnal VSHE; Zaytseva, L.V., Kursova, O.A., Khil'chuk, E.L. (2019). Obosnovannost' i posledstviya povysheniya pensionnogo vozrasta [Justification and consequences of raising the retirement age]. Rossiyskiy yuridicheskiy zhurnal, 2, Zakharov, M.L. (2013). Mezhdunarodnye i rossiyskiye normy pensionnogo obespecheniya: sravnitel'nyy analiz [International and Russian pension provisions: a comparative analysis]. Eds. Tuchkova, E. G., Vasilyeva, Yu. V. Moscow; Zakharov, M.L. (2013). Sotsial'noe strakhovanie v Rossii: proshloe, nastoyashchee i perspektivy razvitiya [Social insurance in Russia: past, present and development prospects]: monograph. Moscow: Prospect; Dmitrieva, O. G. (ed.) (2015). Pensionnye sistemy i pensionnye reformy [Pension systems and pension reforms]. Moscow: Nauka; Roik, V.D. (n.d.). Pozhilye i stareyushchiy sotsium Rossii: vybor modeli zhiznedeyatel'nosti
$\operatorname{Vol}^{\circ} 02$ | nº 01 | ISSN: 2675-7451

https://www.periodicojs.com.br/index.php/gei/index

[Elderly and ageing society in Russia: choosing a model of life]. Moscow: Prospekt; Serebryakova, E.A. (n.d.) Sotsial'no-trudovaya reabilitatsiya i adaptatsiya invalidov i lits pozhilogo vozrasta [Social and labor rehabilitation and adaptation of disabled and elderly people]: monograph. Ed. Buyanova, M. O. et al.

International recommendations and practices for determining the retirement age were reviewed.

Further, in order to determine the scope of guarantees provided under Russian legislation aimed at social support of citizens due to age in the labor market, an analysis of the current legislation, as well as the practice of its application. It used court decisions, the position of the Supreme court of the Russian Federation and the constitutional court of the Russian Federation.

The available special legal documents are considered comprehensively.

To assess the sufficiency and effectiveness of the rules governing the work of retired and pre-retired workers, and the rules aimed at overcoming ageism, the study presents statistical data and research conducted in this area by 


\section{I}

GEENERO E INTERDISCIPLINARIDADE

modern economists, lawyers, specialists in personnel management, etc. Such works are: Ghosheh, N. (2008). Age Discrimination and Older Workers: Theory and Legislation in Comparative Context. Geneva: International labour office; Gimpelson, V. E., Lukiyanova, A., Sharunina, A. (2015). Estimating the Public-Private Wage Gap in Russia: What Does Quantile Regression Tell Us? Working paper no. BRP 104/ EC/2015. Series WP BRP "Economics/EC". Higher School of Economics. P.5., Hedge J. W., Borman, W. C., Lammlein, S. E. (2006). The Ageing Workforce: Realities, Myths and Implications for Organizations. American Psychological Association: Washington, DC., Van Dalen H., Henkens K., Schippers J. 2010. Productivity of older workers: Perceptions of employers and employees. Population and Development Review 36 (2), World Health Statistics 2018: Monitoring health for the SDGs., Klepikova, E. A., Kolosnitsyna, M. G. (2019). Eydzhizm na rossiyskom rynke truda: diskriminatsiya $\mathrm{v}$ zarabotnoy plate [Ageism in the Russian labor market: discrimination in wages], Kolobova, S. V., Sergeenko, Yu. S. (2019). Grazhdane starshego pokoleniya kak sub"ekty
Vol $^{\circ} 02$ | nº 01 | ISSN: 2675-7451

https://www.periodicojs.com.br/index.php/gei/index

trudovogo prava [Citizens of the older generation as subjects of labor law]. Modern law, 6; Lyutov, N.L., Gerasimova, Ye.S. (2016).

Diskriminatsiya v sfere truda: voprosy effektivnosti norm i pravoprimenitel'noy praktiki [Discrimination in the world of work: issues of efficiency of norms and law enforcement practice]. Aktual'nye problemy rossiyskogo prava; Mosina, O. A. (2015). Institut rossiyskoy sotsial'noy politiki $\mathrm{v}$ otnoshenii pozhilykh: opyt sotsiologicheskoy kontseptualizatsii [Institute of Russian social policy in relation to the elderly: experience of sociological conceptualization]. Extended abstract of candidate dissertation (sociological sciences). Tyumen; Novikov, V. A. (2020). Kriticheskie razmyshleniya ob ugolovnoy otvetstvennosti za diskriminatsiyu lits predpensionnogo i bolee starshego vozrasta v sfere trudovykh otnosheniy [Critical reflections on criminal liability for discrimination of persons of preretirement and older age in the field of labor relations]. Aktual'nye problemy rossiyskogo prava; Seregina, L. V. (2019). Nekotorye pravovye problemy zashchity ot bezrabotitsy grazhdan starshego pokoleniya [Some legal 


\section{I}

GÊNERO E INTERDISCIPLINARIDADE

problems of protection from unemployment of citizens of the older generation]. Zhurnal rossiyskogo prava; Frolova, A. (2010). Diskriminatsiya po vozrastu pri priyeme na rabotu [Age discrimination in hiring]. Upravleniye personalom; etc.

\section{Results. Discussion}

\subsection{International legal} support for people due to age.

At the international level, quite a lot of attention has been drawn to the social protection of elderly citizens over the past few decades, which is natural. If in the middle of the $\mathrm{XX}$ century, the ratio of older persons in the world was only $8 \%$, since the beginning of the 2000 s this figure has increased to $10 \%$, and by 2050 it is expected to increase to $20-22 \%$. According to the UN, the total world population is growing by $1.2 \%$ per year, while the number of older persons is increasing by $2-3 \%$ (Department of Economic and Social Affairs...). In Europe, one in five European residents is already over 60 years old (European Commission report on ageing, 2018).

In 1982, the First World Assembly on Ageing was held, which resulted in the adoption of the so-called Vienna international plan of action on ageing approved by the UN General
$\mathrm{Vol}^{\circ} 02$ | nº 01 | ISSN: 2675-7451

https://www.periodicojs.com.br/index.php/gei/index

Assembly on August 5 of the same year (Vienna international plan of action...). This document contains recommendations for action by the global community on ageing and the protection of the rights of older persons.

At the 45th session, the UN General Assembly adopted Resolution 45/106 (1990), which proclaimed the establishment of the International day of older persons - October 1.

On December 16, 1991, Resolution 46/91 approved the UN Principles for older persons under the motto "make the life of the elderly full" (Adopted by General Assembly resolution 46/91... 1991).

The next step was the adoption by the UN General Assembly of Resolution 47/5 dated 16 October 1992 "Declaration on ageing issues", which confirmed the provisions of the Vienna international plan of action and the UN Principles on older persons, established the strategy for action for the decade (1992-2001) and declared 1999 to be the International year of older persons.

The Second World Assembly on ageing was held in Madrid from 8 to 12 April 2002 and resulted in the adoption of the Madrid International Plan of Action on Ageing. 


\section{I}

GÊNERO E

INTERDISCIPLINARIDADE

The most important goals of the Madrid plan are: 1) realization of all human rights and fundamental freedoms for older persons and 2) ensuring the realization of economic, social and cultural rights, as well as civil and political human rights, and the elimination of all forms of abuse and discrimination against older persons.

Acts of the International labour organization include Convention No. 35 (1933) "On insurance of older workers in industry", Convention No. 36 (1933) "On insurance of older workers in agriculture", ILO Convention No. 102 (1952) "On minimum standards of social security", and Convention No. 128 (1967) "On disability, old age and for the loss of a breadwinning spouse".

An important act is the ILO recommendation No. 162 (1980) "On older workers" covers a wide range of life-related issues: equal opportunities, vocational training and counselling, as well as housing, social and health aspects.

Numerous

conferences, assemblies and meetings on this issue demonstrate the relevance of social protection of the elderly in the modern world.

As UN Secretary-General Ban
Vol $^{\circ} 02$ | nº 01 | ISSN: 2675-7451

https://www.periodicojs.com.br/index.php/gei/index

Ki-moon noted in 2009: "older persons are a heterogeneous group that, on the one hand, makes a special contribution to the development of society, and on the other hand, needs special protection and support". (Second World Assembly on Ageing... 2009).

\subsection{Identification of} categories of persons in need of social support due to age.

The main focus on the situation of older persons in terms of their rights is on vulnerability to poverty and violations of their economic and social rights.

Who belongs to the category of older persons? Is it correct to distinguish the elderly (that is, people who have reached old age) as a separate category of the population? The main difficulty lies in the fact that old age itself is a very relative concept.

As a rule, it occurs when a certain physical condition is reached, but even here it is difficult to give a clear answer to the question when this age occurs.

Gerontologists note that ageing is a genetically programmed biological process accompanied by certain agerelated changes in the human body, in which the its adaptation capabilities to the environment are limited. After 


\section{I}

GÊNERO E INTERDISCIPLINARIDADE

reaching maturity, the body's activity gradually weakens. In gerontology, they refer to the fact that this is also a weakening of the main nervous processes, especially the inhibitory one, and a decrease in their mobility (Gamezo, Gerasimova, Gorelova, Orlova, 1999).

In most sciences, old age is linked to a certain age. Scientists have developed various systems of periodization of human age.

The psychologists have found that age limits are very conditional and relative; the onset of a new phase in human development is determined by a complex of social and biological reasons and depends on the specific social conditions of individual human development. Within the framework of gerontology and gerontopsychology, age is studied from the point of view of the psychophysiological features of an elderly person and the extension of the period of active human activity. Along with the change in average life expectancy, the content of the concept of old age also changes.

Today, there are two main approaches in international law. The conditionally retrospective one is based on the number of years lived. It is easier
Vol $^{\circ} 02$ | nº 01 | ISSN: 2675-7451

https://www.periodicojs.com.br/index.php/gei/index

to use, and it has been used as a basis by the developers of the retirement age increase in Russia in 2018. They cited the example of the retirement age in foreign countries without comparing the life expectancy after reaching this age. Another approach can be called predictive. It is based on the estimated life expectancy (15 years) after reaching the set age (Sanderson, Scherbov, 2016). It is interesting that the estimated postretirement survival period was included in the formula for calculating the amount of the funded pension in Russia in 2001 (the accumulated capital was divided by the number of years of survival), but it was not taken into account when determining the retirement age itself. For example, when the average life expectancy of a man in Russia in 2001 was 58.92 (The Demographic Yearbook of Russia, 2017) years and the retirement age was 60 years, the number of months that accumulated capital was divided into in order to determine the monthly amount paid was 228 months (19 years) (Federal law No. 173-FZ, 2001).

Various approaches to age and their interpretation for labor law and partly for social security law were considered in detail in candidate dissertation of $\mathrm{Yu}$. V. Vladimirova 


\section{I}

GÊNERO E INTERDISCIPLINARIDADE

'Significance of employee's age in labor law'. The author came to the conclusion that in terms of law, age is a certain fact of life, which is an averagely defined and normatively fixed stage of personal development, with the onset of which the norms of law associate the occurrence of certain legal consequences: legal personality, rights, duties, and responsibilities. This definition of age allows attributing it to legal facts (Vladimirova, 2002).

For the purposes of social security (insurance) law, the key is not old age itself, but disability as a consequence of old age. In this case, disability due to old age is presumed and does not require proof.

The upper limit of working age or the so-called legal limit of old age was established for a long time by the Soviet, and until 2019 by the Russian pension legislation for men at 60 years, and for women at 55 years (Federal law N 400FZ, 2013).

Soviet scientists pointed out that in addition to medical and biological examination, disability as a basis for providing "includes social assessment. In the norms of law, the state determines which citizens are considered disabled and why. When resolving this issue, the
Vol $^{\circ} 02$ | nº 01 | ISSN: 2675-7451

https://www.periodicojs.com.br/index.php/gei/index

society proceeds not only from the state of health of citizens and their ability to work, but also from considerations of public expediency and the need to exempt certain categories of citizens from public labor" (Ivankina, 1979).

A number of authors even spoke in favor of individualizing the onset of disability and refusing the concept of the fixed age (Acharkan, 1973). Legally, old age cannot be defined in any other way than by indicating the age limit, although it is quite realistic that a particular person can acquire the right to a pension and even receive it while being fully able to work (Azarova, Kozlov, 1983).

The same criteria are used by international organizations when determining the number of people who require support due to old age.

For example, the UN currently defines the elderly as those aged over 64 (Change of the age structure... 2017). Thus, in accordance with article 26 of the ILO Convention No. 102 "On minimal standards of social security" (1952), the established age must not exceed 65 years or it is such an age, which can be determined by competent suthorities with due regard to the working capacity of older persons in the country.

Article 15 of the ILO Convention 


\section{I}

GÊNERO E INTERDISCIPLINARIDADE

No. 128 "On disability, old-age and for the loss of a breadwinning spouse" (1967) specifies that this age may be increased by the competent authority with due regard to demographic, economic and social criteria justified by statistics.

The World Health Organization (WHO) defines the old age as 65 years, and this is again due to the establishment of the retirement age in most developed countries.

\subsubsection{The retirement age} increase in Russia.

It should be noted that in recent years, many countries have decided to increase the retirement age due to the increase in life expectancy and the length of stay in retirement.

Currently, in Western European countries, even with a fairly high retirement age (up to 65-67 years), the average life expectancy in retirement is more than 13-14 years. The ratio between the number of employees and pensioners is continuously decreasing. There is a desire to change expensive pension systems without drastic structural changes and abrupt changes in pension formulas. All reforms and changes in pension systems are 'faceliftlike' in nature and, as a rule, are limited
$\operatorname{Vol}^{\circ} 02\left|n^{\circ} 01\right|$ ISSN: 2675-7451

https://www.periodicojs.com.br/index.php/gei/index

to increasing the retirement age (very gradually, one to two months a year) or building mechanisms to encourage later retirement (Dmitrieva, 2015).

A similar temptation to reduce the cost of the pension system appeared in Russia. However, in addition to demographic and fiscal prerequisites for increasing the retirement age, there are also prerequisites from the labor market, namely, the labor shortage (at least structural) and the absence of youth unemployment (see also Zakharov, n.d.; Dmitrieva, 2015).

V. D. Roik rightly noted: "...the retirement age should be defined using a systematic approach, taking into account the interrelated consideration of a number of factors: the working capacity of older persons; the position of older persons in the labor market; economic opportunities for pension financing, etc (Roik, n.d.).

An increase in the retirement age cannot be considered as an incentive for long-term work, especially in the context of the relatively short retirement period of Russian citizens compared to residents of other states (Denisenko, Varshavskaya, 2017). According to the World Health Organization, in 2016, the healthy life expectancy of Russians was 


\section{।}

E GEneroe

INTERDISCIPLINARIDADE

only 63.5 years (World Health Statistics

$2018 \ldots$, and in order to increase it, the legislative will itself is not enough.

Nevertheless, the lack of funds to maintain the minimum level of pension provision forced the authorities to raise the issue of the retirement age increase in the summer of 2018.

Starting from January 1, 2019, the age was raised by 5 years in Russia. However, the way it was raised drew criticism not only from trade unions and the public, but also from most experts in this field. The main argument was that other ways of modernizing the system like abolition of preferential tariffs, the revision of early retirement, and the increase in the minimum wage were
$\mathrm{Vol}^{\circ} 02$ | nº 01 | ISSN: 2675-7451

https://www.periodicojs.com.br/index.php/gei/index

ignored. Another problem was the haste with which the age was increased. Thus, one of the prominent legal scholars in pension provision M. L. Zakharov pointed out that "it (a decision) should be prepared in advance, comprehensively and carefully. People should understand that it is objectively necessary, it is not carried out for fiscal purposes and not for the sake of increasing the profit of employers, but in order to provide everyone with a decent level of pension provision provided for by the Constitution of the Russian Federation (Zakharov, 2013). The change in the retirement age began on January 1, 2019 and would take a total of 5 years, i.e. the period from 2019 to 2023:

\begin{tabular}{|c|c|c|}
\hline \multirow[t]{2}{*}{ YEAR } & \multicolumn{2}{|c|}{$\begin{array}{l}\text { The year after which the right to an old-age insurance pension will } \\
\text { acrue. }\end{array}$} \\
\hline & Men & Women \\
\hline 2019 & 61 & 56 \\
\hline 2020 & 62 & 57 \\
\hline 2021 & 63 & 58 \\
\hline 2022 & 64 & 59 \\
\hline $\begin{array}{l}2023 \text { and } \\
\text { beyond }\end{array}$ & 65 & 60 \\
\hline
\end{tabular}

Thus, there is practically no adaptation period necessary to prepare everyone and their family for such an important event as retirement, which is associated with people's life plans. 


\section{I}

GÊNERO E

INTERDISCIPLINARIDADE

To mitigate the consequences for citizens for whom the moment of retirement was unexpectedly postponed, the state introduced a new category into the legislation. This category is preretirees, it retained a number of benefits that were previously valid only for persons of retirement age.

For example, the family law has been amended, according to which preretirees have the right to receive child support.

In civil legislation, this category of citizens retains the right to receive a legitimate in the inheritance.

Among the benefits that are reserved for pre-retirees, there also are: free medicines and transportation, a discount on the payment of capital repairs and other housing and communal services, tax benefits, etc.

\subsubsection{Employment and age}

\section{discrimination}

Thus, the pension reform establishes a new legal status for persons of pre-retirement age and, in its essence, simply preserves the existing situation for this category. However, the guarantees provided to them relate mainly to the preservation of previous benefits and are not related to obstacles in the labor market that citizens face
$\mathrm{Vol}^{\circ} 02$ | nº 01 | ISSN: $2675-7451$

https://www.periodicojs.com.br/index.php/gei/index

much earlier than the retirement and even pre-retirement age.

At the same time, the growth of employment of the elderly is observed everywhere. This is due to several reasons. First, the modern economy requires fewer and fewer workers engaged in rough labor. Labor is shifting to the service sector, it is becoming automated and more comfortable. Second, older workers are more educated today. Third, the elderly are in better health. Fourth, the need for labor income continues to be an important factor, which for many pensioners is becoming a necessary addition to a low pension. This situation is particularly characteristic of Russian reality. Fifth, the very fact of having a job increases the subjective life satisfaction of older Russians. In Russia, unfortunately, the opportunities for social activity of the elderly are extremely limited, and there are not enough projects for the socialization of the elderly population, which usually operate in large cities.

Such an example is the Moscow City Government project "Moscow longevity" for the older generation, which helps them lead an active lifestyle and use the city's opportunities for selfrealization for free. The project offers 


\section{I}

GÊNERO E INTERDISCIPLINARIDADE

free sports clubs, creative studios, and educational courses. Classes are aimed at improving health, gaining new knowledge and skills, expanding the social circle and organizing leisure activities for citizens over 55 years of age. Another social project is "Kind bus": a project implemented with the support of the Moscow Government that aims to support citizens of retirement age, increase their mobility and social activity, and introduce them to the cultural life of the capital.

Thus, employment is especially important not only as a source of income, but also as a way of communication and self-realization. It is no accident that, according to the WHO, social activity is a mandatory element of active longevity along with health and safety (including financial), and having a job is one of its important elements.

In 2016, the Government of the Russian Federation approved a Strategy for actions in the interests of older citizens in the Russian Federation until 2025 (Decree of the Government of the Russian Federation No. 164-R, 2016). One of the goals of the Strategy is to create a society for all ages including creating conditions for using the knowledge, experience, and potential of
$\operatorname{Vol}^{\circ} 02\left|n^{\circ} 01\right|$ ISSN: 2675-7451

https://www.periodicojs.com.br/index.php/gei/index

older citizens, taking care of them and providing them with the necessary assistance. It is noted that every year the need to use the labor of older citizens in economy would increase.

But at the same time, the Strategy notes that the problem of providing employment for older citizens is hindered by the negative stereotypes regarding the employment of this category among the employers and in society as a whole. Not all pensioners manage to realize their right to work (Decree of the Government of the Russian Federation No. 164-R, 2016). The unemployment rate in Russia among the population over 60 years in 2018 was 3.5\% (Federal State Statistics Service. Distribution... 2018).

The state is meant to provide feasible employment, guarantees in terms of conditions and remuneration, and to prevent age discrimination in employment. However, ageism is a pervasive phenomenon, based on stereotypes of thinking that an older employee is viewed by the employer as less capable, motivated, and efficient (Van Dalen, Henkens, Schippers, 2010). Employers often believe that older persons are less creative, reluctant to 


\section{I}

GÊNERO E

INTERDISCIPLINARIDADE

learn, and are afraid of changes (Hedge, Borman, Lammlein, 2006).

American magazine ProPublica conducted a study in 2018 and concluded that in America, the vast majority of employees over 50 years of age are being discriminated. In 2019, the magazine published the results of a shocking investigation: many American companies use all sorts of tricks to avoid hiring people of age. For example, when publishing information about vacancies on social networks, employers used settings so that job ads remained visible only to young users.

Why employers avoid to hire older candidates? HR specialists have several reasons:

- the employer's uncertainty that an older employee would be able to work in the company for a long time, for example, because of the worker's health problems;

- poor training of 'aged' employees. People who work all their lives according to their own rules, methods, etc., are extremely hard to acquire new technologies, which are increasingly popular in young, growing and developing companies;

- fear that the employee would not fit into the young team;
$\mathrm{Vol}^{\circ} 02$ | nº 01 | ISSN: $2675-7451$

https://www.periodicojs.com.br/index.php/gei/index

- the employer doesn't know to which position they should higher older persons. In lower positions, a person would look like a black sheep among their twice younger employees who hold the same position. A 50-year-old employee wouldn't fit into a department the head of which is 35 years old. In this case, the boss himself is likely to feel uncomfortable in front of such a subordinate (Frolova, 2010).

However, worse job chances are not the only problem that older workers face. In the course of working life, there is a decrease in career opportunities and relatively low wages for older workers, which is not always due to their low productivity.

Unequal pay is especially typical of the Russian labor market. This is also facilitated by the imperfection of legislation and its practical application. Despite the existence of a norm in the Labor Code of the Russian Federation on the employer's obligation to make equal payment for work of equal value, there are no mechanisms for detecting these violations by employees themselves. The only document containing all the positions and salaries of employees that allows comparing salaries is not provided to employees for review, and 


\section{I}

E GÉnero e

INTERDISCIPLINARIDADE

unions for monitoring. Russian legislation does not contain rules on the maximum ratio of fixed and variable wages, which allows employers to manipulate payments and arbitrarily determine the total amount paid (This problem has been repeatedly stated by trade unions and experts, in particular, in Chapter 8 in Civil Review on the Implementation...).

Therefore, there are enough chances for discrimination in Russian companies: the fixed part of remuneration determined by the employment agreement is no more than $65 \%$ for the "average" Russian employee, and $35-40 \%$ is the so - called variable part, which the employer is not obliged to pay (Gimpelson, Lukiyanova, Sharunina, 2015).

According to the results of a study made by experts from the Higher school of Economics, it can be argued that the maximum salary is reached at the age of 25-44 years. At the age of 50-54, wages are generally lower by about $12 \%$, and at the age of 55-59-by $21 \%$ (all other things being equal). For women, the drop in wages with age is higher than for men (Klepikova, Kolosnitsyna, n.d).

In this regard, the main forces of the state should be aimed at non-
$\mathrm{Vol}^{\circ} 02$ | nº 01 | ISSN: 2675-7451

https://www.periodicojs.com.br/index.php/gei/index

discrimination and ensuring employment and fair income.

An analysis of the specifics of Russian anti-discrimination legislation allows concluding that it is not very effective both in general and in terms of measures aimed at fighting against age discrimination.

Among the controversial norms and gaps in the legal regulation of the prohibition of discrimination in Russia, domestic researchers call the ambiguity of the concept of discrimination itself, the vagueness of the prohibition of indirect discrimination, the ambiguity of judicial practice on discrimination based on age, and the weakness of security legal mechanisms aimed at preventing it (Lyutov, Gerasimova, 2016).

According to the earlier version of part 3 of article 3 of the Labor Code of the Russian Federation, persons who believe that they were abused in terms of labor were entitled to apply to the court for restoration of violated rights, and to the federal labor inspection bodies. In 2006, changes were made to exclude the power to review complaints from employees who have been discriminated in terms of work from the powers of the labour inspectorate. As a result, the ability of discriminated workers to 


\section{,}

protect their rights has been significantly reduced. In this regard, in recent years, the scientific literature has repeatedly raised the issue of the need to return the lost powers of the labor inspectorate.

\subsubsection{Guarantees of labor rights} and protection from discrimination

What additional rules were introduced after the retirement age was raised, and were they able to smooth out the difficulties in the labor market?

For several months during the introduction of the law on the retirement age increase in the media, there were statements like "Finally, the elderly will now be able to work longer and feel young!", "Pushing the retirement age bar will protect older workers in itself", etc.

The question is how?

The reform has not affected and could not affect the legal ability to work. As a general rule, the age limit for concluding an employment contract is not set by law, and the registration of employment relations with persons who have reached the pre-retirement and retirement age is carried out on general terms.

But this was not always the case. The Labor Code of the RSFSR of 1971 had once article 33 that provided for the possibility of termination of an
Vol $^{\circ} 02$ | nº 01 | ISSN: 2675-7451

https://www.periodicojs.com.br/index.php/gei/index

employment contract in case of "reaching the retirement age of an employee with the right to a full old age pension". The article 18.1 "Employment contract with workers and employees who have reached retirement age" gave the organization's administration the right, together with the trade union committee, to maintain labor relations with those employees who have reached retirement age, who work in good faith, with full return, have high labor results and enjoy well-deserved authority in the team. That is, as an exception.

In 1992, these provisions were recognized by the Decision of the Constitutional Court of the RSFSR of February 4, 1992 No. 2 P-3 (Resolution of the Constitutional Court... 1992) as inconsistent with the Constitution of the RSFSR and a number of international legal acts, primarily the ILO Convention on discrimination in employment and occupation of 1958 (No. 111).

To date, there are no additional opportunities for termination of an employment contract or refusal to conclude this contract upon reaching the retirement age in the Russian Federation for this category of citizens!

The only restriction on labor rights that still exists in the legislation is 


\section{I}

GÊNERO E

INTERDISCIPLINARIDADE

the ability to conclude a fixed-term employment contract with old-age pensioners entering into work without taking into account the nature of the work to be done, i.e. even when there is no need for urgency. In the original version of article 59 of the Labor Code of the Russian Federation, a fixed-term employment contract with old-age pensioners was mandatory. But in June 2006, an amendment was made about the "consent of the parties".

This rule raises many questions from experts, including international ones (The European Committee on social rights... 2007). Moreover, it contradicts the logic of the 1992 determination of the Constitutional Court regarding the constitutionality of the provision on the possibility of dismissal of an employee upon reaching retirement age. However, considering the norm on a fixed-term employment contract, the constitutional court recognized the provisions of the Labor Code of the Russian Federation in this matter as consistent with the Constitution. In support of their position, the Constitutional Court determination of 15 May 2007 (Determination of the Constitutional Court... 2007) cited the following arguments: first, not all
Vol $^{\circ} 02$ | nº 01 | ISSN: 2675-7451

https://www.periodicojs.com.br/index.php/gei/index

employees who have reached retirement age are covered by this article, but only those who have received the right to an old-age pension. Accordingly, pensioners, unlike other employees, have a guaranteed source of sustenance. Secondly, the determination states that the conclusion of a fixed-term employment contract is subject to the consent of the parties. In this regard, the opinion expressed by judge O. S. Khokhryakova on this decision found in this issue same as the case considered by the Constitutional Court in 1992, and expressed its disagreement with the determination adopted in 2007, is supported.

Firstly, the financial situation of the employee should not affect his right to work in any way, and secondly, the employee as a weaker party is more often forced to agree to the employer's proposal to set any condition by "the consent of the parties".

The employer certainly has an interest in establishing a fixed-term employment relationship with an older employee (Serebryakova, n.d.). This provision makes it possible to part with a retired employee at the end of the term of such a contract without explaining the reasons. 


\section{I}

\section{GÊNERO E}

INTERDISCIPLINARIDADE

Surprisingly, in the wake of the improvement in the labor market for people of retirement and pre-retirement age, this norm has not been cancelled!

In 2009, a draft bill was submitted to the State Duma of the Federal Assembly of the Russian Federation to exclude old-age pensioners from the list of persons that are allowed to enter into a fixed-term employment contract on the consent of the parties. This draft bill was not supported (Draft law No. 207713-5, n.d.).

As for the rules that provided additional guarantees for the elderly, there were not so many of them in the legislation before the retirement age was increased. Practically, the only reform was article 128 of the Labor Code of the Russian Federation. It states that the oldage pensioners (by age) have the right to additional leave without pay for up to 14 days a year.

What is new in the labor rights of this category of employees?

From January 1, 2019, the Labor Code of the Russian Federation provides for the employer's obligation to release an employee of pre-retirement age from work for two days a year while maintaining their position and average earnings for medical examination. From
$\mathrm{Vol}^{\circ} 02$ | nº 01 | ISSN: $2675-7451$

https://www.periodicojs.com.br/index.php/gei/index

August 11, 2020, employees who have reached the age of forty also have the right to be released from work for one day once a year.

The release would take place on the basis of a written application from the employee and should be agreed with the employer. The norm is really reasonable, given the fact that Russia has not developed a proper culture of taking care of their health. And many employees simply 'do not feel like' spending their day off or vacation days going to the doctor. However, these norms do not affect the situation on the labor market in any way.

There were also minor changes in the procedure for obtaining the status of unemployed and paying unemployment benefits. The law of the Russian Federation "On employment in the Russian Federation" is supplemented by article 34.2 "Additional guarantees of social support for citizens of preretirement age" (Http://www.consultant.ru) that provides for the following rights of citizens of preretirement age who are recognized as unemployed:

1) the right to an extended period of payment of unemployment benefits; 


\section{I}

GEENERO E

INTERDISCIPLINARIDADE

The period of payment of benefits for persons of pre-retirement age is now different from the total period of payment (which was no more than three months in total within 12 months) under the following conditions: no more than 12 months have passed since the last place of work (service), and the dismissal is not a punishment for a disciplinary offense or other guilty actions of the employee. In this case, the payment period may not exceed 12 months in total for 18 months.

However, it should be taken into account that before January 1, 2019, the total period for payment of unemployment benefits was 12 months in total for 18 months. In other words, this rule, which previously applied to all unemployed citizens regardless of their age, has remained in force only for citizens of pre-retirement age. For other citizens, the period for paying unemployment benefits was reduced. In fact, little has changed for the group of unemployed in question: before January 1, 2019, they were also entitled to benefits for 12 months.

2) the right to receive increased unemployment benefits.

The mechanism for determining the amount of benefits has long been
Vol $^{\circ} 02$ | nº 01 | ISSN: 2675-7451

https://www.periodicojs.com.br/index.php/gei/index

criticized. The calculation procedure was established in 1991, when like most countries, in Russia there was mandatory social insurance for unemployment. The benefit was calculated as a percentage of previous earnings, which is typical for insurance systems. However, in the future, insurance was canceled and today the benefit is paid from the federal budget. At the same time, the legislator did not change the formula, but set a very low maximum amount, which the allowance cannot exceed, thus making the calculation mechanism itself meaningless. Until January 1, 2019, the maximum amount of the allowance was 4,900 rubles (while the subsistence minimum in the fourth quarter of 2018 was 1,1069 rubles). From January 1, 2019, the maximum amount was increased to 8,000 rubles, and for preretirees to 11,280 rubles (with the subsistence minimum for the workingage population of 11,653 rubles for the first quarter of 2019).

Thus, the law does not guarantee the payment of benefits in the amount of the subsistence minimum. The maximum and minimum amounts of unemployment benefits are set by the Government of the Russian Federation annually at random. 


\section{।}

GÊNERO E

INTERDISCIPLINARIDADE

One of the main guarantees for people of retirement and pre-retirement age in the labor market during the campaign to raise the retirement age was the expansion of opportunities for training.

Of course, barriers to learning have a negative impact on career, efficiency (Ghosheh, 2008), and even the duration of working life. The actual restriction of access of older persons to professional development and retraining entails a restriction of their access to work.

The Ministry of labor and social protection has prepared programs aimed at the elderly: "Special program of professional training and additional professional education for persons aged 50 years and older, as well as persons of pre-retirement age for the period up to 2024" (Approved by the Order... 2020).

Under this program, citizens who have reached the pre-retirement age will be able to study the most popular professions or get additional education. The program is available to both unemployed and working people.

At the same time, training of employed citizens should be carried out in the direction of employers. Employers' expenses for training
$\mathrm{Vol}^{\circ} 02$ | nº 01 | ISSN: 2675-7451

https://www.periodicojs.com.br/index.php/gei/index

employees of pre-retirement age would be compensated from the funds provided for the implementation of a Special program in the Federal budget and the budgets of the constituent entities of the Russian Federation. The conditions for such compensation are that the employee fully completes training and remains employed by a specific employer. The government of the Russian Federation plans that by the end of 2024, the ratio of employees in the number of people aged 50 and older, as well as those of preretirement age who have completed vocational training or received additional professional education, would be at least 85 percent.

The fact that such employees are still employed would be monitored by the employment service authorities.

However, experts have concerns that training in new professions would not result as expected. The state should solve the problems of ensuring the employment of pre-retirees, the possibility of preserving professions, and not re-training the older generation in new professions, which are often lowskilled and do not correspond to the previous one.

Unemployed people over 50 years of age are given the opportunity to 


\section{I}

GÊNERO E

INTERDISCIPLINARIDADE

retrain only in working professions regardless of what kind of education they had. At the same time, every year the percentage of senior citizens with higher education is growing but their opportunities are below citizens of less educated peers.

There is a need to develop a set of measures that would make hiring older generation more attractive for employers so that the experience and professionalism of the elderly would be of great benefit. Employers could organize training for young professionals with the help of their own experienced employees within their companies (Chayka, 2019).

Another innovation was the introduction of a new article in the Criminal Code of the Russian Federation as compensation for raising the retirement age, which provides for the responsibility of employers-article 144.1 "Unjustified refusal to hire or unjustified dismissal of a person who has reached the pre-retirement age" (Http://www.consultant.ru). It provides for liability in the form of a fine of up to 200,000 rubles in the same amount as wages or other income for 18 months or community service for up to 360 hours.
$\mathrm{Vol}^{\circ} 02$ | nº 01 | ISSN: 2675-7451

https://www.periodicojs.com.br/index.php/gei/index

Will this rule change the position of persons who have reached the preretirement age in the labor market?

First, the law already contains provisions on the prohibition of discrimination that are quite applicable to the persons in question. This is article 136 of the Criminal Code "Violation of equal rights and freedoms of man and citizen", article 5.62. Administrative code, namely "Discrimination", which is understood as violation of rights, freedoms and legitimate interests of man and citizen depending on sex, race, colour, nationality, language, origin, property, family, social and official position, age, place of residence, attitude to religion, convictions, belonging or not belonging to public associations or any social groups.

Secondly, experts have long been aware of the effectiveness of criminal liability in the field of discrimination. The long-standing article 145 of the Criminal Code of the Russian Federation "Unjustified refusal to hire or unjustified dismissal of a pregnant woman or a woman with children under three years of age" has shown its weak effectiveness, since the main problem in the fight against discrimination is not the lack of standards establishing responsibility but 


\section{I}

GÊNERO E INTERDISCIPLINARIDADE

the complexity of proof,. That is why no criminal cases have been initiated in the country for years under such articles.

As a rule, it is about hidden discrimination, when it is not easy to prove the fact of violation of the rights: no employer in their right mind would tell the applicant at the interview that they do not hire him because of his age, and not for other reasons. Moreover, this fact will never be mentioned in the official written refusal to accept a job.

In recent years, only a few cases of criminal prosecution for a crime under article 145 (Novikov, 2020) of the Criminal Code of the Russian Federation are known.

And there have been no changes to the rules that improve the procedure for proving discrimination, such as shifting the burden of proof to the respondent.

Moreover, the norm aimed at preventing the dismissal of senior citizens leads to the opposite effect. Employers do not want to take risks and prefer not to get involved with this category at all rather than later prove that the employee's age was not related to the management decisions made.

\section{Conclusion}




\section{।}

GEENERO E

INTERDISCIPLINARIDADE

of international law and using the experience of foreign countries;

- organize advanced training courses in the field of discrimination for law enforcement officers;

- grant the state labor inspectorate the right to consider complaints of discrimination in labor relations or refer these issues to the competence of a special antidiscrimination body.

Regarding measures aimed at organizing the working conditions of older workers and taking into account their needs, it is necessary to use the methods proposed by the ILO Recommendations No. 162 "On older workers". These include allowing older workers to organize working hours and rest at their own discretion, in particular allowing them to work part-time and on a rolling (flexible) schedule; gradually reducing working hours for all older workers; increasing the length of annual paid leave due to length of service or age; facilitating the appointment of older workers to daytime work after a certain number of years of full or partial shift work; limiting overtime; individualizing workloads and tasks based on their health status, etc.
$\operatorname{Vol}^{\circ} 02\left|n^{\circ} 01\right|$ ISSN: 2675-7451

https://www.periodicojs.com.br/index.php/gei/index

\section{References}

Abdullaeva, E.T., 2018. Stimulation and encouragement of the work of the elderly population. Trudovoe pravo v Rossii i za rubezhom, 2, 41 - 43.

Acharkan, V. A., 1973. Relevant problems of pension provision. In: Dokhody trudyashchikhsya i sotsial'nyye problemy urovnya zhizni naseleniya $\mathrm{v}$ SSSR. Moscow.

Azarova, E.G., Kozlov, A.E., 1983. Personality and social security in the USSR. Moscow. See also Vladimirskaya.

Biggs, S., Carstensen, L., Hogan, P., 2012. Social capital, lifelong learning and social innovation. In: Beard J. L., Biggs S., Bloom D. E., fried L. P., Kalache A., Olshansky S. J. (eds). Global Population Ageing: Peril or Promise? World Economic forum: Geneva.

URL

https://www.weforum.org/reports/global -population-ageing-peril-or-promise

Change of the age structure of the population and sustainable development. Report of the Secretary-General prepared by the population Division of the United Nations Department of economic and social Affairs, April 3-7, 2017.

URL:

https://www.un.org/en/development/des 


\section{I}

a/population/pdf/commission/2017/docu ments/ECN920172/ru.pdf

Chayka, L.N., 2019. Features of legal regulation of labor of pre-retirement workers. Pravo i ekonomika, 11, 68 - 72. URL: http://www.consultant.ru

Civil Review on the Implementation of the RAO UES of Russia in Russia "2020-2030: A Decade of Action for the RAO UES of Russia. Challenges and solutions".

URL:

http://kurs2030.ru/report2020?fbclid=I wAR1W85wEPBbZQJadHMALb7rxNl TI9TvEit4HS6T50DAuPOWO16rWful

$\underline{\text { YqzS }}$

Denisenko, M. B., Varshavskaya, E. Ya., 2017. Working life duration in Russia. Ekonomicheskiy zhurnal VSHE vol. 21, 4, 616. URL: https://ej.hse.ru/en/201721-4.htm

Department of Economic and Social Affairs Population Division, World population ageing: 1950 - 2050. URL: https://www.un.org/en/development/des a/population/publications/pdf/ageing/W PA2015_Report.pdf.

Dmitrieva, O. G., 2015. Pension systems and pension reforms. Moscow: Nauka. European Commission report on ageing, 2018.URL:https://ec.europa.eu/info/pub $\underline{\text { lications/economic-and-financial- }}$
$\operatorname{Vol}^{\circ} 02\left|n^{\circ} 01\right|$ ISSN: 2675-7451

https://www.periodicojs.com.br/index.php/gei/index

affairs-publications_en (access date: 20.08.2020)

Frolova, A., 2010. Age discrimination in hiring. Upravleniye personalom, 21, 3842. URL: http://www.consultant.ru Gamezo, M.V., Gerasimova, B.C., Gorelova, G.G., Orlova, L.M., 1999. Developmental psychology: personality from youth to old age. Moscow.

Ghosheh, N., 2008. Age Discrimination and Older Workers: Theory and Legislation in Comparative Context. Geneva: International labour office. URL:

https://www.ilo.org/wcmsp5/groups/pub lic/---ed_protect/---protrav/--travail/documents/publication/wcms_tra vail_pub_19.pdf

Gimpelson, V. E., Lukiyanova, A., Sharunina, A., 2015. Estimating the Public-Private Wage Gap in Russia: What Does Quantile Regression Tell Us? Working paper no. BRP 104/ EC/2015. Series WP BRP "Economics/EC". Higher School of Economics. URL: https://publications.hse.ru/mirror/pubs/s hare/folder/o9gi6p83ed/direct/17529004 6.pdf.

Hedge, J. W., Borman, W. C., Lammlein, S. E., 2006. The Ageing Workforce: Realities, Myths and Implications for Organizations. 


\section{।}

\section{GẼNERO E} INTERDISCIPLINARIDADE

American Psychological Association: Washington, DC.

ILO global report 'Equality at work: search for answers to calls'. URL: www.ilo.org/declaration.

Ivankina, T.V., 1979. Problems of legal regulation of the distribution of public consumption funds. Izd-vo Leningradskogo un-ta.

Klepikova, E. A., Kolosnitsyna, M. G., 2019. Ageism in the Russian labor market: discrimination in wages. Sovremennoe pravo, 7, 78-82.

Klepikova, E. A., Kolosnitsyna, M. G., (n.d.). Ageism in the Russian labor market: discrimination in wages. URL: https://publications.hse.ru/mirror/pubs/s hare/direct/211147500

Lyutov, N.L., Gerasimova, Ye.S., 2016.

Discrimination in the world of work: issues of efficiency of norms and law enforcement practice. Aktual'nye problemy rossiyskogo prava, 3 .

Mosina, O. A., 2015. Institute of Russian social policy in relation to the elderly: experience of sociological conceptualization. Extended abstract of candidate dissertation (sociological sciences). Tyumen.

Novikov, V.A. (2020). Critical reflections on criminal liability for discrimination of persons of pre-
$\operatorname{Vol}^{\circ} 02\left|n^{\circ} 01\right|$ ISSN: 2675-7451

https://www.periodicojs.com.br/index.php/gei/index

retirement and older age in the field of labor relations. Aktual'nye problemy rossiyskogo prava, 4, 128 - 133. URL: http://www.consultant.ru

Report of the Global Commission on the Future of Labor 'Working for a better future', 2019. International labour office. Geneva: ILO.

Roik, V.D., (n.d.). Elderly and ageing society in Russia: choosing a model of life. Moscow: Prospekt.

Sanderson, W., Scherbov, S. «Age Structure, Mortality and Prospective Ageing», presentation at the United Nations expert group meeting on changing population age structures and sustainable development. Sanderson, S. New York, 13 and 14 October 2016. URL:https://www.un.org/en/developme nt/desa/population/events/pdf/expert/25/ 2016-EGM_Warren \%20Sanderson.pdf. Second World Assembly on Ageing, Report of the Secretary General, 6 July 2009 ,

$\mathrm{A} / 64 / 127$.

URL:

https://www.un.org/esa/socdev/docume nts/reports/Ageing.pdf

Serebryakova, E. A., (n.d.). Social and labor rehabilitation and adaptation of disabled and elderly people: monograph. Ed. Buyanova, M. O.

Seregina, L. V., 2019. Some legal problems of protection from 
unemployment of citizens of the older generation. Zhurnal rossiyskogo prava, 6, 111-125.

Solntsev, A.M., Keburiya, K.O., 2013. K voprosu o sozdanii mezhdunarodnogo dogovora o pravakh pozhilykh lyudey. Sotsial'noye i pensionnoye pravo, 2. URL: http://www.consultant.ru

The Demographic Yearbook of Russia, 2017. Federal State Statistics Service.

URL:

https://rosstat.gov.ru/bgd//regl/B17_16/

Main.htm

Van Dalen, H., Henkens, K., Schippers, J., 2010. Productivity of older workers: Perceptions of employers and employees. Population and Development Review 36 (2).

Vladimirova, Yu. V.б 2002. The meaning of the employee's age in labor law. Candidate dissertation (law sciences). Perm.

World Health Statistics 2018: Monitoring health for the SDGs. URL: https://apps.who.int/iris/bitstream/handl e/10665/272596/9789241565585eng.pdf?ua=1.

Zakharov, M. L., 2013. International and Russian pension provisions: a comparative analysis. Eds. Tuchkova, E. G., Vasilieva, Yu. V. Moscow.
Zakharov, M. L., 2013. Social insurance in Russia: past, present and development prospects: monograph. Moscow: Prospekt.

Zaytseva, L.V., Kursova, O.A., Khil'chuk, E.L., 2019. Justification and consequences of raising the retirement age. Rossiyskiy yuridicheskiy zhurnal, 2, 144-155. URL: http://www.consultant.ru 